\title{
Mechanistic Interventions of Selected Ocimum Species in Management of Diabetes, Obesity and Liver Disorders: Transformative Developments from Preclinical to Clinical
} Approaches

\author{
Nikhil Garg ${ }^{1}{ }^{\mathbb{D}}$, Thakur Gurjeet Singh ${ }^{1, *}(\mathbb{D})$, Heena khan ${ }^{1}$, Sandeep Arora ${ }^{1}$, Amarjot Kaur ${ }^{1}$, Ashi Mannan ${ }^{1}$ \\ 1 Chitkara College of Pharmacy, Punjab, India \\ * Correspondence: gurjeet.singh@ chitkara.edu.in, gurjeetthakur@gmail.com;
}

Scopus Author ID 27667828700

Received: 15.02.2021; Revised: 8.04.2021; Accepted: 12.04.2021; Published: 27.04.2021

\begin{abstract}
Metabolic disorders are usually categorized as inborn metabolism defects, including carbohydrate metabolism deficits in enzymes, amino acids derived from proteins, and fatty acids released from lipids. A metabolic disorder, which arises from elevated body weight, diabetes, and obesity, has reached epidemic proportions in countries. This review discusses the metabolic disorders with respect to diabetes, obesity and liver disorders and their therapeutic management with selective Ocimum species. Ocimum genus contains more than 200 species and is one of the richest sources of diverse phytoconstituents, including fatty acids, saponins, flavonoids, terpenoids, phenols, tannins, etc. that are documented to be beneficial in the management of various metabolic disorders. The potential of selected Ocimum species in metabolic disorders is discussed by reviewing available preclinical and clinical studies and associated mechanisms of action and their effect on gene expression.
\end{abstract}

Keywords: Ocimum; metabolic disorders; diabetes; liver disorder; obesity; gene expression.

(C) 2021 by the authors. This article is an open-access article distributed under the terms and conditions of the Creative Commons Attribution (CC BY) license (https://creativecommons.org/licenses/by/4.0/).

\section{Introduction}

Metabolic disorders are usually categorized as inborn metabolism defects, which also include carbohydrate metabolism deficits in enzymes, amino acids derived from proteins, and fatty acids released from lipids. Insulin resistance, elevating fasting glucose level, up down in liver and lipid markers are the major causes that result in a metabolic disorder like diabetes, obesity, and liver ailments which have reached epidemic proportions in countries [1,2]. It is estimated that up to 2030, out of ten adults, one will have diabetes mellitus. People who are overweight have a relatively higher risk for developing colon cancer, gastric cardia, and cholangiocarcinoma, whereas diabetic patients are prone to neuropathy, nephropathy, and retinopathy that could affect the quality of patient's life and is associated with intense morbidity [3-5]. Though the drugs are available to treat metabolic disorders like liver disorders, obesity, diabetes, etc., as mentioned in tables given below (Tables 1, $2, \& 3$ ), these drugs only resolve symptoms and fail to cure the disorder permanently. Therefore, people rely on herbal therapies that are considered relatively safer and devoid of side effects.

\subsection{Methodology.}

A systematic literature review of PubMed, Bentham, Scopus, and EMBASE (Elsevier) databases was carried out with the help of the keywords like Ocimum Metabolic disorders, Diabetes, 
liver disorder, and obesity till October 2020. This review focuses on clinical and preclinical interventions linked to selected species of Ocimum in metabolic disorders and their mechanistic approaches.

\section{Drugs Used in Metabolic Disorders and their Side Effects}

As shown in the tables below (Tables 1, 2, and 3), drugs are available to treat metabolic disorders such as liver disorders, obesity, diabetes, etc. However, these drugs only treat symptoms and do not cure the disorder permanently. As a result, people rely on herbal therapies, which are thought to be safer and have fewer side effects.

Table 1. Conventional drugs and side effects in diabetes.

\begin{tabular}{|c|c|c|c|c|c|}
\hline S. No & Drug class & $\begin{array}{l}\text { Representative } \\
\text { Drug }\end{array}$ & Mechanism of Action & Side effects & Ref. \\
\hline 1. & Insulin analogs & Insulin & $\begin{array}{l}\text { Lower the blood glucose level by } \\
\text { enhancing the uptake of peripheral } \\
\text { glucose by skeletal muscle cell } \\
\text { and adipocyte cell }\end{array}$ & $\begin{array}{l}\text { Weight gain, insulin } \\
\text { allergies, hypoglycemia }\end{array}$ & [9] \\
\hline 2. & Sulphonylureas & Glyburide & $\begin{array}{l}\text { These drugs enhance the } \\
\text { pancreatic beta cells for the } \\
\text { secretion of insulin, i.e., shows the } \\
\text { Hypoglycemic effect. }\end{array}$ & $\begin{array}{l}\text { Hypoglycemia, weight } \\
\text { gain, CVS disorders, } \\
\text { rashes, itching, damage } \\
\text { to bone marrow, a } \\
\text { stomach infection }\end{array}$ & [9] \\
\hline 3. & GLP-1 agonists & Exenatide & $\begin{array}{l}\text { Increases the secretion of glucose } \\
\text { dependent insulin from beta cells } \\
\text { in pancreatic. }\end{array}$ & $\begin{array}{l}\text { GIT effects, cancer risks } \\
\text { also the cardiovascular } \\
\text { disorders }\end{array}$ & [10] \\
\hline 4. & $\begin{array}{l}\text { DPP-4 } \\
\text { inhibitors }\end{array}$ & Saxagliptin & $\begin{array}{l}\text { It degrades the levels of glucagon } \\
\text { hence low down the secretion of } \\
\text { glucagon }\end{array}$ & $\begin{array}{l}\text { Risk of cancer, kidney } \\
\text { damage }\end{array}$ & [9] \\
\hline 5. & $\begin{array}{l}\text { Thiazolidinedio } \\
\text { ns }\end{array}$ & Pioglitazone & $\begin{array}{l}\text { Stimulates the transcription of } \\
\text { genes for glucose control }\end{array}$ & $\begin{array}{l}\text { Weight gain, hepatitis, } \\
\text { water retention }\end{array}$ & [11] \\
\hline 6. & $\begin{array}{l}\text { Dual PPAR } \\
\text { agonists }\end{array}$ & Saroglitazar & $\begin{array}{l}\text { It has both actions to improve the } \\
\text { insulin resistance as well as } \\
\text { decreases the high blood } \\
\text { triglycerides }\end{array}$ & Pyrexia & [9] \\
\hline 7. & $\begin{array}{l}\text { Alpha } \\
\text { Glucosidase } \\
\text { inhibitors }\end{array}$ & Acarbose & $\begin{array}{l}\text { Reduces the synthesis the blood } \\
\text { glucose }\end{array}$ & GIT disorders, hepatitis & [9] \\
\hline 8. & Amylin analogs & Pramlintide & $\begin{array}{l}\text { Helps in blood glucose control by } \\
\text { reducing gastric emptying, by } \\
\text { encouraging satiety through } \\
\text { hypothalamic receptors }\end{array}$ & Allergic reactions & [11] \\
\hline 9. & $\begin{array}{l}\text { SGLT-2 } \\
\text { inhibitors }\end{array}$ & Canagliflozin & $\begin{array}{l}\text { It helps to reduce the glucose } \\
\text { reabsorption in the kidney, which } \\
\text { results in an increase inthe } \\
\text { excretion of urinary glucose and } \\
\text { reduces the glucose in the plasma }\end{array}$ & Glycosuria & [9] \\
\hline 10. & Biguanides & Metformin & $\begin{array}{l}\text { It lowers the production of hepatic } \\
\text { glucose and lowers the absorption } \\
\text { of glucose in the intestine }\end{array}$ & Lactic acidosis & [11] \\
\hline
\end{tabular}

\subsection{Statins.}

Statins are the active hydrolyzed drugs which are the HMG-CoA reductase inhibitors for lowering cholesterol levels, so we can say these are the cholesterol-lowering agent. Statins also had an influence on the LDL and HDL secretion in patients with high cholesterol levels. 


\subsubsection{Simvastatin.}

Simvastatin is a more potent compound to increase the apoA1 synthesis. It is also clinically proved that it might increase the plasma HDL concentration levels, but it decreases the LDL cholesterol concentrations.

\subsubsection{Atorvastatin.}

It helps to elevate the overproduction of hepatic lipoproteins [6] also enhances hepatic insulin signaling and sensitivity.

\subsection{Ezetimibe.}

It inhibits the dietary and biliary cholesterol intestinal absorption also reduces the LDL-C levels [7].

\subsection{Insulin sensitizing agents.}

2.3.1. Rosiglitazone.

It enhances hepatic insulin signaling but decreases lipoprotein overproduction [8].

\subsubsection{Metformin.}

It decreases the rates of more hepatic glucose production. It helps to improve its use of insulin-stimulated glucose through the extra liver tissue. It lowers diabetes development in those with obese and overweight insulin-resistant personal. It is the mainly preferred drug in patients with diabetes mellitus type 2 .

\subsection{GLP receptor agonists.}

\subsubsection{Exenatide.}

It inhibits apoptotic beta cells. It enhances the rate of blood pressure, lipids, and also hepatic transaminase levels in the body. The most common side effect is that it gives reduction to the infiltration of liver fat.

\subsection{DPP 4 inhibitors.}

\subsubsection{Sitagliptin.}

It improves the blood glucose controls of diabetes 2 in adults. It ameliorates the secretion of insulin by improving the secretion of proinsulin ratio.

Table 2. Conventional drugs and side effects in liver disorders.

\begin{tabular}{c|l|l|l|l} 
S. No & Drug & Mode of action & Adverse effects & Reference \\
\hline 1. & Metadoxine & $\begin{array}{l}\text { It is a serotonin receptor antagonist that } \\
\text { acts on the GABA transaminase enzyme } \\
\text { and reduces its activity }\end{array}$ & Nausea, fatigue, headache & {$[9]$} \\
\hline 2. & Ondansetron & $\begin{array}{l}\text { It is a 5HT3 receptor antagonist which is } \\
\text { used in various therapies like cancer } \\
\text { therapy, radiation, or surgery to prevent } \\
\text { vomiting and nausea }\end{array}$ & $\begin{array}{l}\text { Constipation, drowsiness, } \\
\text { diarrhea, fatigue }\end{array}$ & \\
\hline
\end{tabular}




\begin{tabular}{c|l|l|l|l}
\hline S. No & Drug & Mode of action & Adverse effects & Reference \\
\hline 3. & Silymarin & $\begin{array}{l}\text { It has a hepatoprotective and antioxidant } \\
\text { activity on the liver also inhibits the } \\
\text { fibrogenesis in liver }\end{array}$ & $\begin{array}{l}\text { Abdominal bloating, } \\
\text { itching, indigestion also } \\
\text { some allergic reactions }\end{array}$ & {$[12]$} \\
\hline 4. & $\begin{array}{l}\text { L- Ornithine L- } \\
\text { Aspartate }\end{array}$ & $\begin{array}{l}\text { It stimulates the urea cycle } \\
\text { height loss, wound }\end{array}$ & {$[9]$}
\end{tabular}

Table 3. Conventional drugs and side effects in obesity.

\begin{tabular}{|c|c|c|c|c|}
\hline S. No & Drug & Mode of action & Adverse effects & Reference \\
\hline 1. & Phentermine & $\begin{array}{l}\text { It suppresses the Sympathomimetic } \\
\text { amine activity }\end{array}$ & $\begin{array}{l}\text { Insomnia increases the } \\
\text { blood pressure and the pulse } \\
\text { rate, constipation, severe } \\
\text { headache }\end{array}$ & {$[13]$} \\
\hline 2. & Diethylpropion & $\begin{array}{ll}\text { Sympathomimetic } & \text { appetite } \\
\text { suppressant } & \end{array}$ & $\begin{array}{l}\text { Palpitation, headache, } \\
\text { constipation increases the } \\
\text { B.P. as well as the pulse rate }\end{array}$ & {$[13]$} \\
\hline 3. & Zonisamide & Having an anticonvulsant activity & $\begin{array}{l}\text { Sweating, tremors, } \\
\text { GIT effects, insomnia, and } \\
\text { fatigue }\end{array}$ & {$[13]$} \\
\hline 4. & Topiramate & Also anticonvulsant activity & $\begin{array}{lr}\text { Fatigue, } & \text { memory } \\
\text { impairment, } & \text { somnolence, } \\
\text { stomach pain } & \\
\end{array}$ & [13] \\
\hline 5. & Orlistat & It inhibits the pancreatic lipase & $\begin{array}{l}\text { Stomach pain, oily stools, } \\
\text { low down the absorption of } \\
\text { the fat-soluble vitamins }\end{array}$ & [13] \\
\hline
\end{tabular}

\section{Importance of Herbal Drugs in the Management of Metabolic Disorders like Obesity, Liver Disorder, and Diabetes}

Natural products are being utilized as traditional medicinal products from ancient times. These resources have contributed significantly to drug discovery. Indeed herbal formulations have been developed from natural products for health-promoting effects. Herbal formulations are affordable and can be associated with having a pharmacological effect with minimal side effects, so they are used as alternatives to conventional therapies [14,15]. Herbal products are rich sources of flavonoids; terpenoids, saponins, fatty oils, glycosides, etc., are used to treat diabetes, obesity and liver disorders, etc. The herbal formulations can be used as anti-diabetic, anti-obesity agents, and hepatoprotective for more effectiveness and few side effects in preclinical and clinical studies, as the herbal formulations have no side effects. The current therapeutic approaches (such as just four major groups of oral hypoglycaemic drugs viz: sulfonylurea and pioglitazone, biguanide, glucosidase inhibitors) are largely ineffective. These are also chemically synthetic drugs with certain significant side effects, such as liver disorders, lactic acidosis, and diarrhea. Many of the researchers move towards nature for the collection of some of the herbals with their less toxic effects more solutions. One of the traditionally used medicinal plant genus is the Ocimum species of Ocimum genus in Tropical and subtropical areas of Africa, Tropical Asia, and tropical portions of America's level an altitude of over $1700 \mathrm{~m}$ from water level [16]. These are used traditionally in the management of metabolic disorders like diabetes, liver disorders, obesity. It contains a diverse class of phytoconstituents possessing antioxidants, antidiabetics, anti-obesity, hepatoprotective activities (Table 4). The present review discusses the role of selected \& potentially important Ocimum species in managing metabolic disorders like obesity, diabetes, and hepatoprotection (Figure 1). Also, various preclinical and clinical studies and their mechanism of action are discussed to develop Ocimum species as anti-obesity, anti-diabetic, and hepatoprotective drugs (Figure 2). 


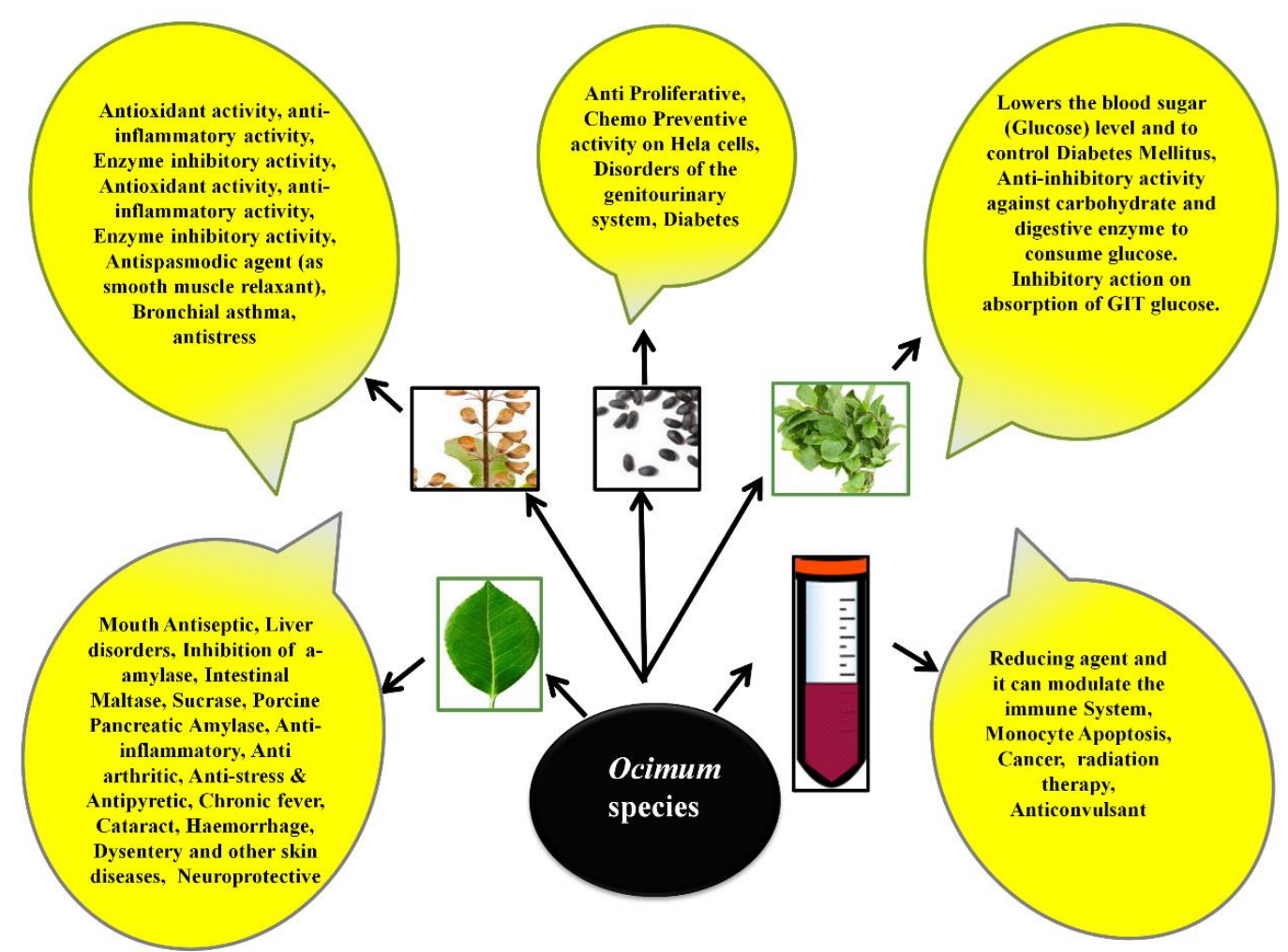

Figure 1. Pharmacological role of the Ocimum species in metabolic disorders preclinical studies on Ocimum species with their reported mechanisms.

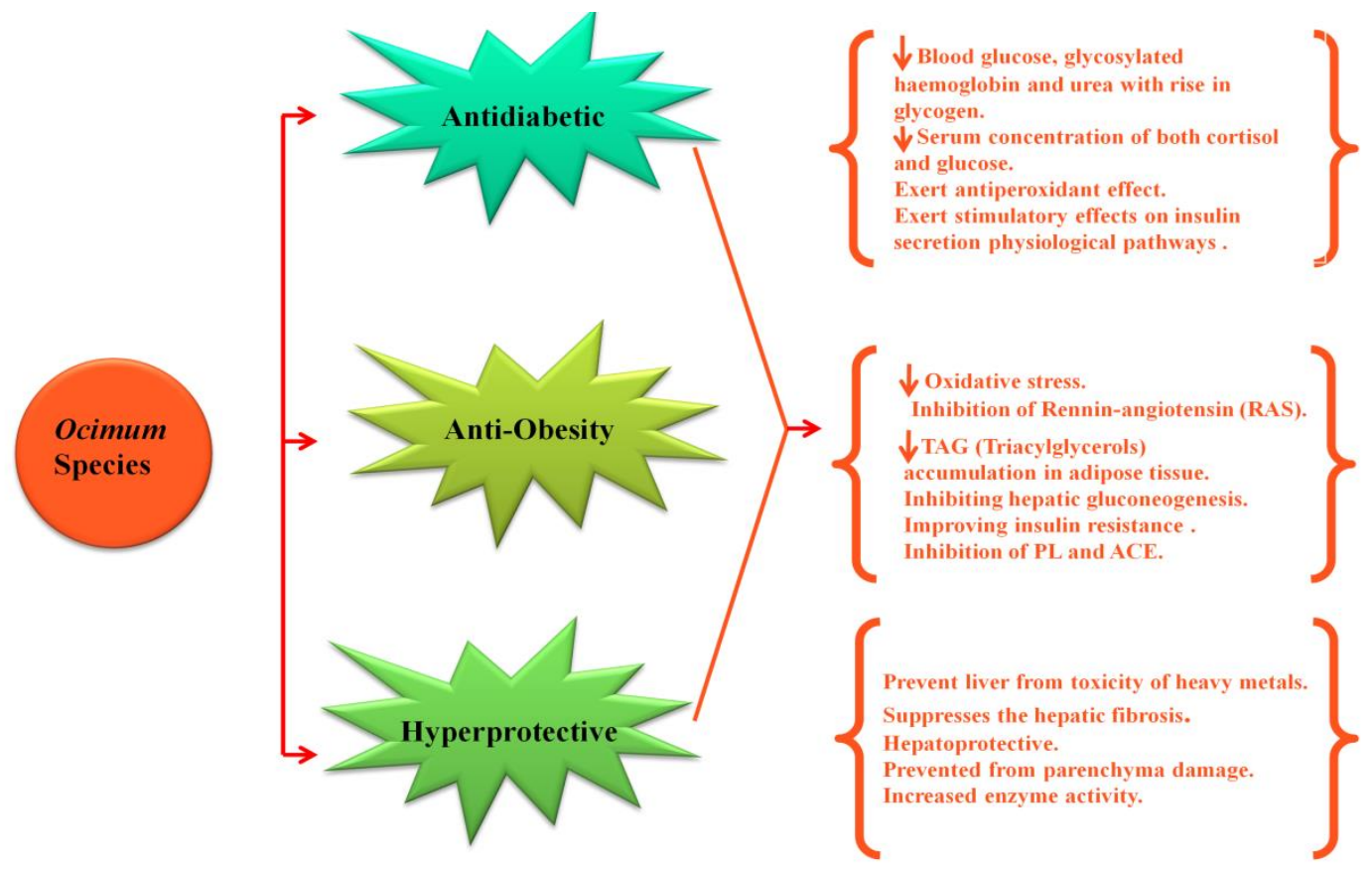

Figure 2. Role of Ocimum species in metabolic disorders as anti-diabetic, anti-obesity, and hepatoprotective.

\subsection{Obesity.}

Increasing the incidence of overweight obesity is a global health issue because excessive weight gain poses an increased risk for different diseases, such as cardiovascular diseases, diabetes, liver disorders, and cancers[17]. Epidemiologically, in lower economy countries, obesity primarily affects middle-aged people, whereas relatively high-economy countries affect all age groups[18]. This increased rate of obesity also leads to an economic burden on a country [19]. The body mass index (BMI), which was measured as weight in kilograms divided by the height in square 
meters, closely correlates with excessive fatty tissue and is therefore used for obesity measurement. Based on the percentage of the body fat and the morbidity data, the normal BMI limits for the Asians are lower (Normal BMI: $18.0-22.9 \mathrm{~kg} / \mathrm{m}^{2}$, Overweight: $23.0-24.9 \mathrm{~kg} / \mathrm{m}^{2}$, Obesity: $>25 \mathrm{~kg} / \mathrm{m}^{2}$ ) [20]. Both obesity and metabolism-related with the highest mortality, mainly related to cardiovascular disease (CVS) [21]. Recently, obesity and metabolism have emerged as solid, main risk factors for chronic kidney disease (CKD) and renal end-stage disease (ESRD). The pancreatic lipase (PL) plays an important role in the digestion of lipids, as bulk hydrolysis is caused by pancreatic lipase (50$70 \%$ ) of total dietary fats [22]. The activation of the rennin-angiotensin system (RAS) has one of the possible mechanisms reported through which obesity may lead to high blood pressure, i.e., hypertension and higher cardiovascular risk [23]. Thus, obesity is associated with further disorders, and thus, finding a treatment strategy for obesity is of prime importance.

\subsection{Diabetes.}

The two major types of diabetes mellitus (DM), insulin-dependent diabetes mellitus (IDDM), i.e., Type I DM and Non-insulin-dependent (NIDDM), i.e., Type II DM, Even with the use of clinically available insulin analogs and oral antihyperglycaemic medications, epidemiological research and clinical trials firmly support the view that frequent use of these agents cannot prevent long-term complications such as diabetic retinopathy, neuropathy, nephropathy, foot infections, atherosclerosis and other associated cardiovascular events including progression-related hypertension, obesity, dyslipidemia and hypercoagulability [24-26]. The major limitation of insulin is that its interaction with Poor patient compliance, possible dosage errors, diabetic ketoacidosis, local tissue necrosis, nerve damage, while costs and untreatable hypoglycemia remain a significant limiting factor [27]. Studies show that so many oral anti-hyperglycaemic agents have failed to maintain normal blood glucose levels for a prolonged period, especially among the elderly [24] and during pregnancy causes gestational diabetes [28]. Therefore the production of successful antidiabetic agents remains one of the world's highest public health priorities.

\subsection{Hepatic disorder.}

The liver is structurally and functionally heterogeneous and contains a wide range of different types of cells, like hepatocytes, immune cells (adaptive and innate immune system), including Kupffer cells, lymphocytes stellate cells, and progenitors. The liver is at the junction of the portal blood supply from the stomach and peripheral organs. A common clinical syndrome is a non-alcoholic fatty liver disease (NAFLD), driven by causes other than alcohol use or some other well-established hepatic injury. NAFLD is pathologically distinguished by a diffuse accumulation of fat in the liver cells (steatosis) while also being a significant factor in developing insulin resistance, type 2 diabetes, and cardiovascular disease.A certain proportion of NAFLD patients was developed to non-alcoholic steatohepatitis (NASH) and eventually to cirrhosis and hepatocellular carcinoma [29]. Studies have shown that intestinal microbiota modification can play a significant role in NAFLD growth and progression. Changing microbiota composition using prebiotics such as inulin-type fructans reduces hepatic steatosis and de novo lipogenesis [30]. Genetics, immunity, dietary components and intestinal microbiota may be the cause of the complex clinical image of alcoholic liver disease (ALD)[31]. 


\section{Role of Herbal Drugs in Managing Metabolic Disorder}

Plants are one of the main medicinal sources. Today the vast number of medicines used comes from plants, like Morphine from Papaver somniferum, Aswagandha from Withania somnifera, Ephedrine from Ephedra vulgaris[32], Atropine from Atropa belladonna, Reserpine from Roulphia serpentina[33], etc. The medicinal plants are secondary plant metabolites (potential drug sources) and essential oils of therapeutic value. The main benefits assumed for medicinal plants' therapeutic use in metabolic disorders are their protection and being economical, effective, and easy to access. In traditional therapeutic methods, medicinal plants were used to effectively regulate the various disease conditions such as bronchial asthma, chronic fever, cold, cough, malaria, dysentery, epilepsy, diabetes, diarrhea, arthritis, emetic syndrome, skin diseases, the bite of insects, etc. also to treat intestinal, hepatic, cvs and immunological disorders [34-36]. Eventually, medicinal plants' properties and therapeutic uses were studied in detail and experimental data documented by the ancient practitioners in Ayurveda (an indigenous medicinal system), which is a fundamental basis of ancient medical science in India [37].

\subsection{Ocimum species a valuable medicinal genus.}

The Sanskrit term Ocimum connotes 'the incomparable ones' with tremendous potential for disease treatment and prevention [38]. It is a mainly valued culinary aromatic genus of the Lamiaceae family with medicinal properties, which is the Indian subcontinent indigenous and has been used for more than 3000 years in Ayurvedic medicine [39]. For its healing powers, Ocimum is sometimes referred to as the "Elixir of Life" in the Indian Ayurveda and also has been known for its treating properties in many health problems.

\subsubsection{Prominent species of Ocimum genus.}

\subsubsection{Ocimum gratissimum Linn.}

It is mainly found in warm and temperate Indian regions also known as Vana, or wild Ocimum (dark green leaves). The plant grows to one to two feet tall and the stem and branches are light yellow or green. The leaves are sharp, oval, pointing and one to two inches long. It stimulates nerve endings which cause a sensation of tingling. The leaves taste like cloves; hence they are widely used for vegetable flavouring etc. [40].

\subsubsection{Ocimum americanum Linn.}

It is found throughout India in fields and wastelands. A pubescent erect, heavily branched herb, 15-60 cm high with branches of sub quadrangular striations. Whitish pink flowers grow in elongated racemes. The fruit is small; when wetted, the nutlets are pitted and mucilaginous [41].

\subsubsection{Ocimum sanctum Linn.}

Known as Ocimum tenuiflorum, Ocimum is being used in Ayurveda for centuries for its rich healing properties. Ocimum, the Queen of Herbs, India's legendary 'Incomparable One,' is one of the most saintly and cherished of the many healthy and healing herbs of the oriented [42]. It is an erect herb 30-75 cm tall that may be grown in most parts of India. The leaves are long $2.5-5 \mathrm{~cm}$ and wide 1.6-3.2 cm, oblong and elliptical. The smell and taste are aromatic and strong. 


\subsubsection{Ocimum basilicum Linn.}

Known as sweet basil, it belongs to the family of Lamiaceae and is commonly cultivated in African, Asian, and South American countries for its medicinal properties and culinary use. Sweet basil extracts are used to treat diabetes also in cardiovascular diseases [43]. Although distinct species with Ocimum tenuiflorum have DNA six times less than Ocimum gratissimum [44], they are traditionally used in the same manner for treating similar diseases

Table 4. Phytoconstituents and pharmacological uses of Ocimum genus.

\begin{tabular}{|c|c|c|c|c|}
\hline Ocimum species & Plant Part & Active Constituents & Pharmacological uses & References \\
\hline O. gratissimum & Leaves & $\begin{array}{l}\text { Eugenol, methyl eugenol, } \\
\text { cis-ocimene, trans- } \\
\text { ocimene, pinene, camphor, } \\
\text { germacrene- D, trans- } \\
\text { caryophyllene, farnesene } \\
\text { and l-bisabolene, oleanolic } \\
\text { acid }\end{array}$ & $\begin{array}{l}\text { Mouth antiseptic, liver } \\
\text { disorders, hypoglycemic effect, } \\
\text { antioxidant, anti-inflammatory, } \\
\text { antimicrobial, neuroprotective }\end{array}$ & {$[45]$} \\
\hline O. gratissimum & Seed & $\begin{array}{l}\text { Pentoses, hexoses, uronic } \\
\text { acid and lipids and thymol }\end{array}$ & $\begin{array}{l}\text { Anti-proliferative as well as } \\
\text { chemopreventive activity }\end{array}$ & [46] \\
\hline O. gratissimum & $\begin{array}{l}\text { aqueous extract } \\
\text { of leaves }\end{array}$ & $\begin{array}{l}\text { Tannins, } \\
\text { triterpinoids, } \\
\text { carbohydrates }\end{array}$ & $\begin{array}{l}\text { Reducing agent and it can } \\
\text { modulate the immune System, } \\
\text { Monocyte apoptosis }\end{array}$ & [46] \\
\hline O. basilicum & Leaves & $\begin{array}{l}\text { Estragole, 3,7-dimethyl, } \\
\text { trans-alpha-bergamotene, } \\
\text { citral, eucalyptol, } \\
\text { levomenthol, and beta- } \\
\text { myrcene. }\end{array}$ & $\begin{array}{l}\text { Inhibition of alpha-amylase } \\
\text { intestinal maltase and Sucrase, } \\
\text { porcine pancreatic amylase }\end{array}$ & [47] \\
\hline O. sanctum & Leaves & $\begin{array}{l}\text { Ursolic acid flavonoids } \\
\text { such as apigenin, } \\
\text { polyphenols, anthocyanins } \\
\text { and luteolin, eugenol, } \\
\text { thymol, or sesquiterpene } \\
\text { alcohols }\end{array}$ & $\begin{array}{lr}\text { Anti-inflammatory, } & \text { anti- } \\
\text { arthritic, } & \text { anti-stress, } \\
\text { antipyretic, chronic fever, } \\
\text { cataract, } \\
\text { dysentery, other skin diseases }\end{array}$ & [48] \\
\hline O. sanctum & Whole Plant & $\begin{array}{l}\text { Eugenol, thymol, palmitic } \\
\text { acid, saponins, flavonoids, } \\
\text { tannins etc. }\end{array}$ & Lowers the blood glucose level & [49] \\
\hline O. sanctum & Flower Tops & $\begin{array}{l}\text { Cirsilineol, cirsimaritin, } \\
\text { isothymusin, isothymonin, } \\
\text { apigenin, rosmeric acid }\end{array}$ & $\begin{array}{l}\text { Antispasmodic agent (as a } \\
\text { smooth muscle relaxant), } \\
\text { bronchial asthma, anti-stress }\end{array}$ & {$[14]$} \\
\hline O. sanctum & Seeds & $\begin{array}{l}\text { Fatty oils, palmitic acid, } \\
\text { stark acid, linolenic acid } \\
\text { and linoleic acid, also } \\
\text { contains oleic acid }\end{array}$ & $\begin{array}{l}\text { Disorders of the genitourinary } \\
\text { system }\end{array}$ & {$[14]$} \\
\hline O. americanum & $\begin{array}{l}\text { Flowers and } \\
\text { leaves }\end{array}$ & $\begin{array}{l}\text { Gallic acid, quinic acid, } \\
\text { caftaric acid, caffeic acid, } \\
\text { ellagic acid, jasmonic acid, } \\
\text { palmitic acid, oleic acid, } \\
\text { arachidic acid }\end{array}$ & $\begin{array}{l}\text { Antioxidant activity, anti- } \\
\text { inflammatory activity, enzyme } \\
\text { inhibitory activity }\end{array}$ & {$[50]$} \\
\hline
\end{tabular}

\subsection{Anti-diabetic Potential of Selected Ocimum species.}

Herbal medicines are constantly being studied using the animal disease model in expectation of the development of a relatively safe anti-diabetic plant-based drug. Ocimum sanctum ethanolic extracts substantially decrease blood glucose, glycosylated hemoglobin, and urea with such a subsequent increase in streptozotocin (STZ) induced diabetic rats throughout glycogen and hemoglobin [42]. The extract has increased insulin and peptide levels and resistance to glucose [41]. The Phytoconstituents of Ocimum sanctum leaf extracts has stimulating effects on insulin secretion 
that may underlie its reported anti-diabetic action [52]. Grover proposed treatingOcimum sanctum extract for 30 days to normal rats fructose-fed considerably lowered serum glucose level [53]. However, Ocimum sanctum does not affect hyperinsulinemia in any significant way. A possible mechanism for lowering blood glucose levels by Ocimum sanctum in male mice could be via reducing both serum cortisol and glucose concentration and antiperoxidant effect. In another study, the effect Ocimum sanctum on three major carbohydrate metabolism enzymes Glucokinase (GK), Hexokinase (HK), and Phosphofructokinase (PFK), along with insulin-dependent (skeletal muscle and liver) glycogen content and insulin-independent tissue (kidney and brain), were studied [54] in STZ $(65 \mathrm{mg} / \mathrm{kg})$ model of diabetes in rats. The administration of extracts at $200 \mathrm{mg} / \mathrm{kg}$ for 30 days leads to a reduction of approximately 9.06 and $24.4 \%$ in plasma glucose levels on the $15^{\text {th }}$ and $30^{\text {th }}$ day. Ocimum sanctum leaf powder was fed for a duration of one month at one percent in normal as well as diabetic rats; also, the test shows a significant decrease in fasting blood sugar urogenic acid, total amino acids levels. This indicates the hypoglycaemic impact of $O$. sanctum in diabetic rats.

Ocimum gratissimum leaf fractions had an anti-diabetic activity which was recorded in a newly designed Type 2 diabetic (T2D) model [55]. The $O$. gratissimum plant comprises active Phytoconstituents attenuating the increased glucose level and thus indicating a potent therapy for type 1 diabetes [56,57]. The leaf fractions of Ocimum gratissimum were used for the Type 2 diabetic model in diabetic rats [55]. The latest animal model T2D provided evidence-based data indicating the anti-diabetic effect of $O$. gratissimum leaf aqueous fractions, comprising Phytoconstituents nhexane, chloroform, ethyl acetate, and n-butanol, resulted in decreasing the blood glucose levels. The potential benefits of the $O$. gratissimum leaf fractions may be attributable to enhanced insulin sensitivity and beta-cell function due to alkaloids, flavonoids, saponins and/or tannins present within O. gratissimum leaf [58] fractions and the effective therapeutic dose is $250 \mathrm{mg} / \mathrm{kg}$ oral. It was observed that this dose decreased hyperglycemia among diabetic rats by $29.3 \%$ at $4 \mathrm{~h}$ after oral administration [55]. The aqueous extract of the leaves of the O. gratissimum boosts up the hematological properties in the diabetic rats caused by the alloxan at the dose rate of $400 \mathrm{mg} / \mathrm{kg}$ orally and low down the blood glucose level also inhibits the anemia with their antioxidant properties [59].The anti-hyperglycemic function of $O$. gratissimum leaves with their inhibitory ability against carbohydrate and SGLT1-mediated digestive enzymes to consume glucose. The $\alpha$ starch in the diet is metabolized into glucose, especially by $\alpha$-amylase and maltase in the digestive tract. The inhibitory ability of $O$. gratissimum leaves extract on the absorption of gastrointestinal (GIT) glucose and provides the theoretical evidence for $O$. gratissimum extract's antihyperglycemic impact [60]. The elevated blood glucose level in mice following oral administration in $\alpha$-starch and glucose was blocked by pre-administering $O$. gratissimum leaves extract, although the maltase and amylase were less inhibited by the $O$. gratissimum extract [61]. The extract of $O$. basilicum treatment substantially $(\mathrm{P}<0.05)$ reduced the concentration of fasting blood glucose at dose levels 100 and $200 \mathrm{mg} / \mathrm{kg}$ and significantly enhance the average body weight in the treated groups [62]. The extract induced a dose-dependent enhancement in the volume of glycogen in the liver, although it lowered levels of alanine transferase and aspartate transferase in a non-dosedependent manner. The Ocimum basilicum extract hasthe ability to inhibit the endogenous release of glucose, also glycogenolysis inhibition, or it may stimulate glycogenesis. Ocimum basilicum is also confirmed to have preventive effects on the liver also have antihyperglycaemic activity. These promote the release of insulin and inhibit glucose production from the pancreas in the liver; also, glycogen synthesis increases. Extract of $O$. basilicum leaves [63] demonstrated a statistically significant reduction in blood glucose between both the diabetic control group and the treatment group metformin or $O$. basilicum in $100,200,400 \mathrm{mg} / \mathrm{kg}$ body weights, so the leaves of $O$. basilicum 
can be used to reduce the blood sugar level and the advanced end products with glycation in diabetic rats [64]. Furthermore, Ocimum plants are reported to be beneficial in managing diabetic complications. The compounds caffeic acid, oleanolic acid, linalool, eugenol, ursolic acid, saponins possessing anti-inflammatory, urea and creatinine reducers, $\alpha$-glucosidase and alpha-amylase inhibitory effects, antioxidant were identified in Ocimum genus that might be associated with health-promoting effects in diabetic -neuropathy, -nephropathy and -retinopathy (Table 5, Figure $3)$.

Table 5. Role of Ocimum species in managing diabetic secondary complications.

\begin{tabular}{|c|c|c|c|c|c|}
\hline Diabetic Complications & Species & $\begin{array}{l}\text { Plant } \\
\text { extracts }\end{array}$ & $\begin{array}{l}\text { Constituent } \\
\mathrm{s}\end{array}$ & Activity & Reference \\
\hline Diabetic Retinopathy & Ocimum sanctum & $\begin{array}{l}\text { Ethanolic } \\
\text { extract }\end{array}$ & $\begin{array}{l}\text { Oleanolic } \\
\text { acid }\end{array}$ & $\begin{array}{l}\text { Inhibit Vascular } \\
\text { Endothelial Growth } \\
\text { Factor Receptor- } 2 \\
\text { (VEGFR2) }\end{array}$ & {$[84]$} \\
\hline \multirow[t]{3}{*}{ Diabetic Neuropathy } & $\begin{array}{l}\text { Ocimum } \\
\text { gratissimum }\end{array}$ & $\begin{array}{l}\text { Hexane } \\
\text { extract }\end{array}$ & $\begin{array}{l}\text { Linalool, } \\
\text { Eugenol }\end{array}$ & $\begin{array}{l}\text { Inhibit } \alpha \text { - amylase } \\
\text { and } \alpha \text {-glucosidase, } \\
\text { Antioxidant. }\end{array}$ & {$[85]$} \\
\hline & Ocimum sanctum & $\begin{array}{l}\text { Methanolic } \\
\text { extract }\end{array}$ & Saponin & $\begin{array}{l}\text { Antioxidant and } \\
\text { reducing calcium } \\
\text { levels }\end{array}$ & {$[66]$} \\
\hline & $\begin{array}{l}\text { Ocimum } \\
\text { basilicum }\end{array}$ & $\begin{array}{l}\text { Hexane } \\
\text { extract }\end{array}$ & $\begin{array}{l}\text { Linalool, } \\
\text { Eugenol }\end{array}$ & $\begin{array}{l}\text { Inhibit } \alpha \text { - amylase } \\
\text { and } \alpha \text {-glucosidase, } \\
\text { Antioxidant. }\end{array}$ & {$[62,86,87]$} \\
\hline \multirow[t]{3}{*}{ Diabetic Nephropathy } & $\begin{array}{l}\text { Ocimum } \\
\text { gratissimum }\end{array}$ & $\begin{array}{l}\text { Alcoholic } \\
\text { extract }\end{array}$ & Eugenol & $\begin{array}{l}\text { Down regulation of } \\
\text { Transforming } \\
\text { growth factor- } \beta \text {, } \\
\text { Reduction in urea } \\
\text { and creatinine. }\end{array}$ & {$[88]$} \\
\hline & Ocimum sanctum & $\begin{array}{l}\text { Ethanolic } \\
\text { extract }\end{array}$ & Ursolic acid & $\begin{array}{l}\text { Antioxidant and } \\
\text { anti-inflammatory }\end{array}$ & [89] \\
\hline & $\begin{array}{l}\text { Ocimum } \\
\text { basilicum }\end{array}$ & $\begin{array}{l}\text { Phenolic } \\
\text { extract }\end{array}$ & Caffeic acid & $\begin{array}{l}\text { suppression of } \\
\text { autophagy } \\
\text { regulatory miRNAs }\end{array}$ & {$[90]$} \\
\hline
\end{tabular}

4.2.1. Mechanistic interventions of selected Ocimum species in diabetes.

Diabetes, one of the most common metabolic disorders, is mainly characterized by insulin secretion or insulin action defects. With insulin deficiency, the body tissues, the liver, and adipose tissues use glucose from the blood circulation. This leads to increased blood glucose levels, known as hyperglycemia [65]. Ocimum species known to have a strong therapeutic potential, i.e., antihyperglycemic effect, and eugenol, a phenolic compound of the essential oils, are found in different Ocimum species been found to lower the blood glucose level. A diabetic study was done in vivo showing that eugenol reduced blood glucose levels via inhibiting $\alpha$-glucosidase, activation of PKC pathway, RAS \& increase of TGF- $\beta$ and non-enzymatic glycation. The polyphenols, caffeic acid, p-coumaric acid of aqueous extracts of Ocimum sanctum leaves, Chicoric acid show an anti-diabetic effect as reported [66]. Pathophysiology of diabetes suggests the involvement of free radicals in the development of diabetic complications, [67] as free radicals are capable of damaging cellular molecules, DNA, proteins, and lipids leading to altered cellular functions. Many recent studies reveal that Ocimum species capable of neutralizing free radicals effectively decrease $\mathrm{Ca} 2+$ levels attributed to its antioxidant effects and reduce the severity of diabetic complications, e.g., neuropathy [65]. Ocimum may also increase insulin receptor sensitivity and stimulate B-cells releasing insulin, resulting in decreased glucose levels. Significant reduction in "fasting blood 
glucose, total amino acid, total lipid, uronic acid, total cholesterol, and triglyceride" indicated the hypoglycemic and hypolipidemic effects of Ocimumin diabetic rats. [62, 66] (Figure 3).

\subsection{Anti-obesity potential of selected Ocimum species.}

In obesity, $O$. basilicum plays a role as an antispasmodic, carminative, stomachic, and also $O$. basilicum, along with $O$. gratissimum leaves may be consumed as food supplements to treat obesity and obesity-related hypertension and to avoid oxidative stress. Pancreatic lipase (PL) plays a vital role in efficient lipid digestion as it is primarily for the hydrolysis of total dietary fats. It is the main enzyme that hydrolyzes triglyceride into glycerol and fatty acids, thus facilitating its uptake. Consequently, it is widely used as an index to assess therapeutics' potential effectiveness as anti-obesity agents [68]. Rennin-angiotensin (RAS) activation has been described as one of the possible mechanisms by which obesity may lead to hypertension and higher cardiovascular risk [22]. Experimental evidence has shown that the rennin angiotensin system (RAS) is triggered in obesity; it has also been reported to be involved in the pathophysiology of obesity-related hypertension [69].

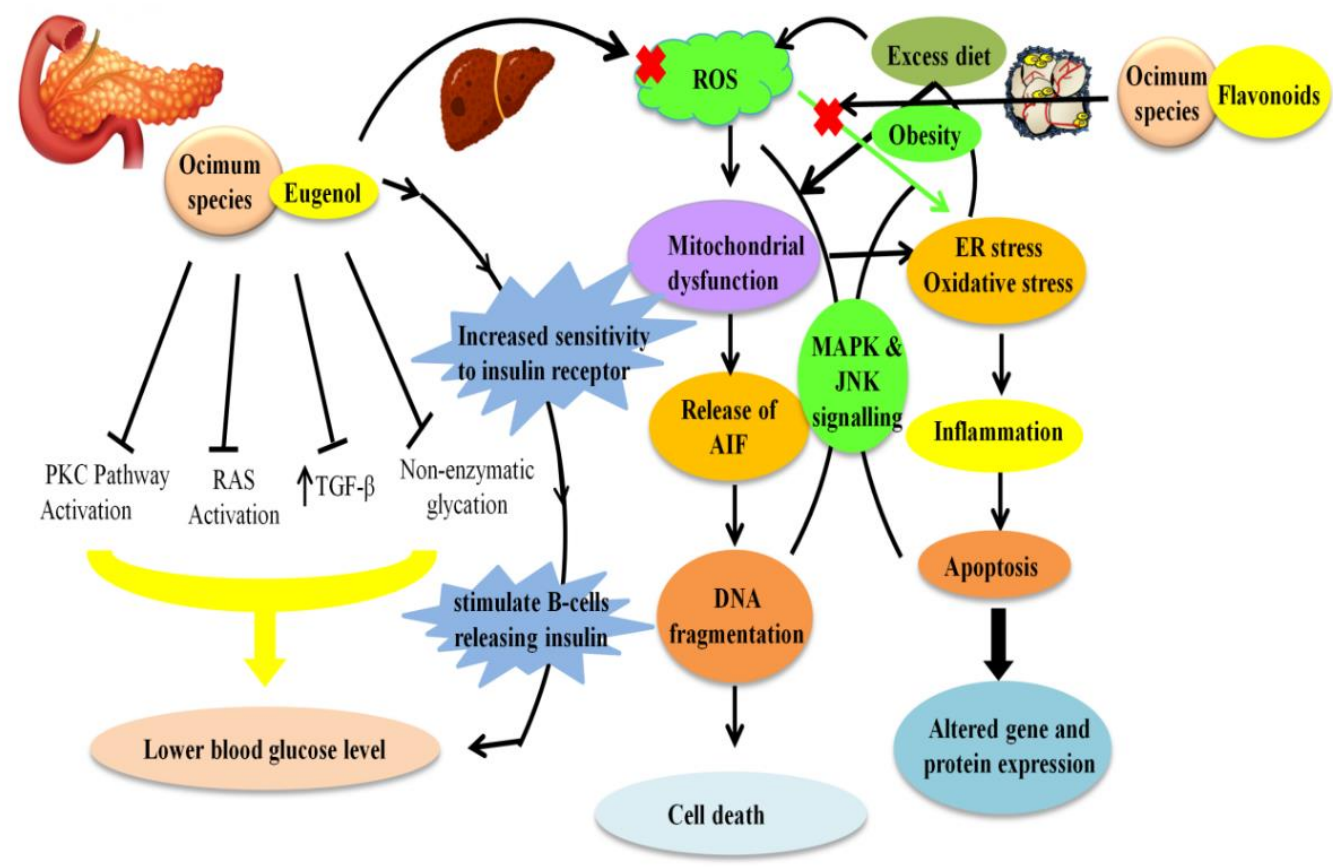

Figure 3. Pictorial presentation of various Tranduction pathways modulated by Ocimum species in metabolic disorders as Antidiabetic, Anti-Obesity and Hepatoprotective.

The angiotensin 1-converting enzyme (ACE) plays a key role in blood pressure control and normal cardiovascular function in the RAS. It catalyzes the transformation of angiotensin I into angiotensin II, which is known to raise blood pressure. Consequently, inhibition of ACE is an effective strategy for treating and managing obesity-induced hypertension [68]. O. basilicum and O. gratissimum are documented to have inhibitory effects on two main enzymes (PL and ACE) involved in vitro in obesity and hypertension. O. gratissimum had an ACE inhibitor activity greater than basilicum. This may be attributed to the presence of a large amount of luteolin (flavonoid) occurring in $O$. gratissimum $(2.01 \mathrm{mg} / \mathrm{g}$ ) and ellagic acid (phenolic acid) not identified in $O$. basilicum [69] as luteolin had better ACE inhibitor activity. Thus, O. santum and O. gratissimum leaves should be consumed as food supplements to control obesity-related hypertension and avoid oxidative stress that characterizes both disorders. The administration of $O$. sanctum decoction lowering the body weight, which was associated with lowering the triacylglycerols (TAG) 
accumulation in adipose tissue, decreased hypertrophy of adiposities, and diminished intestinal TAG digestion and absorption, as shown in increased TAG fecal excretion, and $O$. sanctum exerted the most beneficial effect. These results indicate that $O$. sanctum decoction decreases fasting blood glucose by inhibiting hepatic gluconeogenesis and improving insulin resistance [71].

\subsubsection{Mechanistic interventions of selected Ocimum species in hepatotoxicity.}

The liver carry ou tbody's normal metabolic homeostasis as well as biotransformation, detoxification and excretion of various endogenous and exogenous compounds and is a major organ attacked by ROS. Liver damage caused by natural, industrial toxins [72, 73] or drugs is common but hardly recognized. Eugenol, flavonoid, and ursolic acid components present in Ocimum sanctum leaves have free radical scavenging and anti-lipoperoxidation effects. Free radicals are capable of mitochondrial dysfunctioning, which initiate AIF release and cause DNA fragmentation resulting in cell death. On the other hand, ROS may also lead to activation of some pathways such as MAPK \& JNK, causing a decrease in Bcl2 \& Bclxl damaging cellular molecules [74]. Ocimum species contribute to discontinue this entire process and prevent cell death. The hepatoprotective effect of Ocimum sanctum is due to the antioxidant properties of its constituents \&membranestabilizing property [75]. Moreover, the fixed oil of Ocimum sanctum comprises linoleic acid, which is responsible for its anti-inflammatory activity and reversing the inflammatory features associated with hepatic injury. Administration of the alcoholic extract of Ocimum sanctum leaves showed significant hepatoprotective activity, as shown previously in other studies[74] (Figure 3).

The liver carryout body's normal metabolic homeostasis as well as biotransformation, detoxification and excretion of various endogenous and exogenous compounds and is a major organ attacked by ROS. Liver damage caused by natural, industrial, or pharmaceutical toxins [72, 73] is common but underreported. The components of Ocimum sanctum leaves, such as eugenol, flavonoid, and ursolic acid, have radical scavenging activity and anti-lipoperoxidation properties. Free radicals are capable of mitochondrial dysfunctioning, which initiate AIF release and cause DNA fragmentation resulting in cell death. On the other hand, ROS may also lead to activation of some pathways such as MAPK \& JNK, causing a decrease in Bcl2 \& Bclxl damaging cellular molecules [74]. Ocimum species contribute to discontinue this entire process and prevent cell death. The hepatoprotective effect of Ocimum sanctum is due to the antioxidant properties of its constituents \& membrane-stabilizing property [75]. Moreover, the fixed oil of Ocimum sanctum comprises linoleic acid, which is responsible for its anti-inflammatory activity and reversing the inflammatory features associated with hepatic injury. The administration of an alcoholic extract of Ocimum sanctum leaves had significant hepatoprotective activity, as had been shown in previous studies[74] (Figure 3).

\subsection{Hepatoprotective potential of Selected Ocimum species.}

O. Sanctum leaf extracts may prevent the liver from the toxicity of heavy metals. $\mathrm{CCl}_{4}$ causing the liver injury is dependent on its metabolism to the highly reactive radical trichloromethyl $\left(\mathrm{CCl}_{3}\right)$, which initiates lipid peroxidation. This results in the hepatotoxicity of the $\mathrm{CCl}_{4}$ by initiating lipid peroxidation in the membranes [76]. The current findings indicate that the $O$. sanctum has strengthened the histological changes and increased enzyme activity caused by $\mathrm{CCl}_{4}$ in liver function. This shows that $O$. sanctum has effectiveness in the prevention of hepatotoxicity to $\mathrm{CCl}_{4}$. $O$. Sanctum hepatoprotective effects on experimental liver damage appeared in the study [77], and it also reported that $O$. santumin case of $\mathrm{CCl}_{4}$-induced parenchymal damage may suppress hepatic 
fibrosis and protects the liver. However, the data obtained indicates that $\mathrm{CCl}_{4}$-induced liver fibrosis in rats has resulted in a significant reduction in serum albumin and a significant rise in overall protein; these are clinically effective synthetic hepatic functionalmarkers[76]. A triterpene-rich extract from hairy root cultures $O$. basilicum has been evaluated for hepatoprotective action against extracts from the aerial parts and normal explant roots. Recently, it has been shown that triterpenes such as oleanolic, ursolic, and glycyrrhetinic acids and their derivatives are active in inhibiting $\mathrm{CCl}_{4-}$ induced experimental hepatotoxicity. $\mathrm{CCl}_{4}$, a well-known model compound for chemical hepatic injury induction, [78] oral administration of a hairy root extract at doses of $200 \mathrm{mg} / \mathrm{kg}$ lowered the liver oxidative stress. MDA (malondialdehyde) is a large lipid peroxidation agent which is used as a marker for oxidative liver damage. The hairy root extract's protective impact on the liver injury was not statistically different from Silymarin (milk thistle extract), a commonly used natural hepatoprotective agent. It has been evaluated that $O$. americanum leaves at medium dose $200 \mathrm{mg} / \mathrm{kg}$ and high dose $400 \mathrm{mg} / \mathrm{kg}$ show the hepatoprotective effects on the liver or hepatic damage in rats caused by the paracetamol [79]. The $O$. americanum leaves may increase the total protein [69] and albumin in the serum [80], and also there is an increase in the levels of the total bilirubin (TBIL), alkaline phosphate (ALP), aspartate transaminase(AST), alanine transaminase [81-83] (ALT) were reported.

4.4.1. Mechanistic interventions of selected Ocimum species in obesity.

Excess diet leads to obesity which further causes mitochondrial dysfunction, ER stress, oxidative stress, inflammation, and apoptosis, altering gene \& protein expression via MAPK \& JNK signaling. Systemic oxidative stress isa common feature of obesity and obesity-related hypertension, liver disorder, and diabetes [91]. Oxidative stress arises due to increased generation of free radicals and reactive oxygen species (ROS), with the attendant reduction in the antioxidant defense system, in the obese, further damaging DNA, lipids, and protein. Angiotensin II (AG-II) also induces oxidative stress, which plays a key role in developing hypertension [67]. Though, various previous studies have demonstrated that Ocimum species are rich in flavonoids, and phenolic acids can scavenge free radicals. The ability of the $O$. basilicum and $O$. gratissimum leaves extracts to scavenge free radicals is a sign that they could help alleviate oxidative stress in obesity and obesity-related other disorders [91] (Figure 3).

\section{Effect of Selected Ocimum Species on Gene Expression}

The chief phenolic elements extracted from $O$. gratissimum and $O$. basilicum have been reported to significantly affect the gene expression of the insulin regulatory \& proliferative genes and glucose transporter 2 in treated islets, explaining its ability in reducing the blood glucose level [92]. $O$. basilicum $L$. exerts an anti-inflammatory effect in adipocytes via suppressing the inflammatory signaling pathway through a decrease in Tnfrsf9 gene expression. Also, Nfib1 gene expression was low with $O$. basilicum L., suggesting that the Ocimum extracts influenced TLR4NF- $\kappa \mathrm{B}$ signaling $[93,94]$. The genes that play a direct role in atherogenesis are "LDRL, LxRalpha [95], PPARs, CD-36", as these genes regulate cytotoxin production, lipid metabolism, and cellular activity within the arterial wall. Polyphenols extracted from $O$. sanctum L. have a direct effect on the transcription of these genes in cultured human mononuclear cells (HMC) in the presence of polyphenols extracted from $O$. sanctum $\mathrm{L}$. These polyphenolic extracts have shown an inherent capacity to prevent the transcriptional expression of such genes in metabolic disorders [96]. 


\section{Conclusions}

Ocimum species are highly revered for their health-promoting effects in the traditional system of medicines. Preclinical and clinical investigations showed that Ocimum species, particularly $O$. basilicum, $O$. sanctum, $O$. gratissimum and $O$. americanum are devoid of any toxic effects and have the potential to normalize blood glucose levels and lipid profile, inhibit lipase activity, ameliorate chemical-induced hepatotoxicity, and treat diabetic -neuropathy, -nephropathy and -retinopathy. Also, the Ocimum genus contains phenols, terpenoids, flavonoids, tannins, and steroids documented to be responsible for the observed biological effects of these species. However, more rigorous studies with larger sample sizes and longer durations giving insights into the further mechanism of action and development of standardized formulations are certainly required to develop these species as drugs for managing metabolic disorders and related comorbidities.

Table 6. Clinical studies of selected Ocimum species in metabolic disorders.

\begin{tabular}{|c|c|c|c|c|c|}
\hline S. No & Study Title & Participants & $\begin{array}{l}\text { Ocimum } \\
\text { Formulations }\end{array}$ & Outcome measures & References \\
\hline 1 & $\begin{array}{l}\text { Randomized } \\
\text { controlled }\end{array}$ & $\begin{array}{l}40 \text { male adults } \\
\text { T2DM } \\
\text { (45-55 years) }\end{array}$ & Leaves & $\begin{array}{l}\text { fasting blood } \\
\text { glucose activity }\end{array}$ & [97] \\
\hline 2 & $\begin{array}{l}\text { Randomized } \\
\text { parallel-group }\end{array}$ & $\begin{array}{l}30 \\
\text { Obesity } \\
(17-30 \text { years })\end{array}$ & Leaves & $\begin{array}{l}\text { Enhances body mass } \\
\text { index and lipid levels }\end{array}$ & [91] \\
\hline 3 & $\begin{array}{l}\text { Controlled } \\
\text { parallel-group }\end{array}$ & $\begin{array}{ll}30 & \text { adults } \\
\text { T2DM } & \end{array}$ & Leaf powder & $\begin{array}{l}\text { Significant post- } \\
\text { prandial } \\
\text { glucose \& fasting } \\
\text { blood }\end{array}$ & [98] \\
\hline 4 & $\begin{array}{l}\text { Randomized } \\
\text { single-blind } \\
\text { parallel-group }\end{array}$ & $\begin{array}{ll}200 & \text { adults } \\
\text { Gouty } & \\
\text { arthritis } & \\
\end{array}$ & Tincture of plant & $\begin{array}{l}\text { Reduces } \\
\begin{array}{l}\text { serum } \\
\text { levels }\end{array}\end{array}$ & [99] \\
\hline 5 & $\begin{array}{l}\text { Randomized, } \\
\text { placebo-controlled }\end{array}$ & $\begin{array}{ll}100 & \text { adults } \\
(\geq 40 \text { years }) & \end{array}$ & $\begin{array}{l}\text { Aqueous } \\
\text { Leaves }\end{array}$ & $\begin{array}{l}\text { Enhances lipid } \\
\text { levels, increases } \\
\text { blood glucose, and } \\
\text { rise BP }\end{array}$ & {$[100]$} \\
\hline 6 & $\begin{array}{l}\text { Randomized, } \\
\text { controlled parallel }\end{array}$ & $\begin{array}{l}60 \\
\text { T2DM adults } \\
(30-65 \text { years })\end{array}$ & $\begin{array}{l}\text { Leaves } \\
\text { glibenclamide } \\
\text { drug }\end{array}$ & $\begin{array}{l}\text { Significant fasting } \\
\text { blood } \\
\& \quad \text { postprandial } \\
\text { glucose } \\
\text { reduced HBA1c }\end{array}$ & [101] \\
\hline 7 & $\begin{array}{l}\text { Randomized } \\
\text { placebo-controlled }\end{array}$ & $\begin{array}{ll}40 & \text { adults } \\
\text { T2DM } & \\
\text { (45-55 years) } & \\
\end{array}$ & $\begin{array}{l}\text { Aqueous } \\
\text { leaves }\end{array}$ & $\begin{array}{l}\text { Significant } \\
\text { improvement } \\
\text { in lipid profile }\end{array}$ & [44] \\
\hline 8 & $\begin{array}{l}\text { Randomized, } \\
\text { clinical trial }\end{array}$ & $\begin{array}{l}90 \text { male adults } \\
\text { T2DM } \\
\text { (40-60 years) }\end{array}$ & $\begin{array}{l}\text { Powder } \\
\text { Ocimum leaves }\end{array}$ & $\begin{array}{l}\text { Improved } \mathrm{T} 2 \mathrm{DM} \\
\text { symptoms: polydipsi } \\
\text { a, } \\
\text { polyphagia, \& BP }\end{array}$ & [44] \\
\hline 9 & $\begin{array}{l}\text { Randomized } \\
\text { control }\end{array}$ & $\begin{array}{l}22 \text { healthy } \\
\text { adults } \\
(22-37 \text { years })\end{array}$ & Ethanolic extract & $\begin{array}{l}\text { Reduction in lipid } \\
\text { profile }\end{array}$ & {$[44]$} \\
\hline 10 & $\begin{array}{l}\text { Randomized } \\
\text { control }\end{array}$ & $\begin{array}{l}5 \quad \text { adults } \\
\text { psychosomatic } \\
(60-80 \text { years })\end{array}$ & $\begin{array}{l}\text { Powder } \\
\text { whole plant }\end{array}$ & $\begin{array}{l}\text { Significant } \\
\text { improvement } \\
\text { in lipid profile }\end{array}$ & {$[102]$} \\
\hline 11 & $\begin{array}{ll}\text { Clinical } & \text { study } \\
\text { open-label } & \end{array}$ & $\begin{array}{l}50 \quad \text { Female } \\
\text { adults } \\
\text { hypotensive } \\
(18-30 \text { years) }\end{array}$ & $\begin{array}{l}\text { Fresh juice of } \\
\text { leaves }\end{array}$ & $\begin{array}{l}\text { Significant decrease } \\
\text { in Blood pressure }\end{array}$ & {$[103]$} \\
\hline
\end{tabular}




\begin{tabular}{|c|c|c|c|c|c|}
\hline S. No & Study Title & Participants & $\begin{array}{l}\text { Ocimum } \\
\text { Formulations }\end{array}$ & Outcome measures & References \\
\hline 12 & Controlled group & $\begin{array}{l}27 \\
\text { T2DM/MeS } \\
(45-65 \text { years })\end{array}$ & $\begin{array}{l}\text { Powder of } \\
\text { leaves }\end{array}$ & $\begin{array}{l}\text { Enhances lipid } \\
\text { levels, } \\
\text { blood glucose levels, } \\
\text { glycated } \\
\text { proteins (HbA1c) \& } \\
\text { UA }\end{array}$ & [44] \\
\hline 13 & $\begin{array}{l}\text { Randomized, } \\
\text { single-blind, } \\
\text { Placebo-controlled } \\
\text { cross-over }\end{array}$ & $\begin{array}{l}40 \quad \text { adults } \\
\text { T2DM } \\
(41-65 \text { years })\end{array}$ & $\begin{array}{l}\text { Powder of } \\
\text { leaves }\end{array}$ & $\begin{array}{l}\text { Significant decrease } \\
\text { in fasting blood } \\
\text { glucose, } \\
\text { prandial } \\
\text { glucose and } \\
\text { glucose }\end{array}$ & [44] \\
\hline 14 & $\begin{array}{l}\text { Randomized } \\
\text { placebo-controlled } \\
\text { cross-over }\end{array}$ & $\begin{array}{l}20 \quad \text { adults, } \\
\text { hypertension } \\
(45-64 \text { years })\end{array}$ & Fresh Juice of leaves & $\begin{array}{l}\text { Significant decrease } \\
\text { in blood pressure }\end{array}$ & [44] \\
\hline 15 & $\begin{array}{l}\text { Randomized } \\
\text { placebo-controlled }\end{array}$ & $\begin{array}{l}16 \quad \text { adults, } \\
\text { hypertension } \\
(45-64 \text { years) }\end{array}$ & Fresh Juice of leaves & $\begin{array}{l}\text { Significant decrease } \\
\text { in blood pressure }\end{array}$ & [44] \\
\hline
\end{tabular}

\section{Funding}

None.

\section{Acknowledgments}

The authors are grateful to the Chitkara College of Pharmacy, Chitkara University, Rajpura, Patiala, Punjab, India, for providing the necessary facilities to carry out the research work.

\section{Conflicts of Interest}

\section{There are no conflicts of interest.}

\section{References}

1. Yaribeygi, H.; Farrokhi, F.R.; Butler, A.E.; Sahebkar, A. Insulin resistance: Review of the underlying molecular mechanisms. J. Cell. Physiol. 2019, 234, 8152-8161, https://doi.org/10.1002/jcp.27603.

2. Singh, R.; Rao, H.K.; Singh, T.G. Neuropathic pain in diabetes mellitus: Challenges and future trends. Obesity Medicine 2020, 18, 100215, https://doi.org/10.1016/j.obmed.2020.100215.

3. Kant, R.; Singh, T.G.; Singh, S. Mechanistic approach to herbal formulations used for urolithiasis treatment. Obesity Medicine 2020, 19, 100266, https://doi.org/10.1016/j.obmed.2020.100266.

4. Rani, V.; Deep, G.; Singh, R.K.; Palle, K.; Yadav, U.C.S. Oxidative stress and metabolic disorders: Pathogenesis and therapeutic strategies. Life Sci. 2016, 148, 183-193, https://doi.org/10.1016/j.lfs.2016.02.002.

5. Singh, T.G.; Sharma, R.; Kaur, A.; Dhiman, S.; Singh, R. Evaluation of renoprotective potential of Ficus religiosa in attenuation of diabetic nephropathy in rats. Obesity Medicine 2020, 19, 100268, https://doi.org/10.1016/j.obmed.2020.100268.

6. Adiels, M.; Olofsson, S.-O.; Taskinen, M.-R.; Borén, J. Overproduction of Very Low-Density Lipoproteins Is the Hallmark of the Dyslipidemia in the Metabolic Syndrome. Atertio. Thromb. Vasc. Biol. 2008, 28, 1225-1236, https://doi.org/10.1161/ATVBAHA.107.160192.

7. Phan, B.A.P.; Dayspring, T.D.; Toth, P.P. Ezetimibe therapy: mechanism of action and clinical update. Vascular health and risk management 2012, 8, 415, https://dx.doi.org/10.2147\%2FVHRM.S33664.

8. Czech, M.P.; Tencerova, M.; Pedersen, D.J.; Aouadi, M. Insulin signalling mechanisms for triacylglycerol storage. Diabetologia 2013, 56, 949-964, https://link.springer.com/article/10.1007/s00125-013-2869-1.

9. Bardisi, W.M.; Khorsheed, M.M.; Magliah, F.; Magliah, A.F. Efficacy of insulin analogues in diabetic patients attending primary care centers. Saudi Med. J. 2015, 36, 829, https://dx.doi.org/10.15537\%2Fsmj.2015.7.11409. 
10. Fu, Z.; R. Gilbert, E.; Liu, D. Regulation of Insulin Synthesis and Secretion and Pancreatic Beta-Cell Dysfunction in Diabetes. Curr. Diabetes Rev. 2013, 9, 25-53, https://doi.org/10.2174/157339913804143225.

11. Zhang, L.-H.; Kamanna, V.S.; Ganji, S.H.; Xiong, X.-M.; Kashyap, M.L. Pioglitazone increases apolipoprotein AI production by directly enhancing PPRE-dependent transcription in HepG2 cells. J. Lipid Res. 2010, 51, 2211-2222, https://doi.org/10.1194/jlr.M004481.

12. Vargas-Mendoza, N.; Madrigal-Santillán, E.; Morales-González, Á.; Esquivel-Soto, J.; Esquivel-Chirino, C.; y González-Rubio, M.G.-L.; Gayosso-de-Lucio, J.A.; Morales-González, J.A. Hepatoprotective effect of silymarin. World J. Hepatol. 2014, 6, 144, https://dx.doi.org/10.4254\%2Fwjh.v6.i3.144.

13. Kang, J.G.; Park, C.-Y. Anti-obesity drugs: a review about their effects and safety. Diabetes Metab. J. 2012, 36, 13, http://dx.doi.org/10.4093/dmj.2012.36.1.13.

14. Ekta; Gupta, M.; Kaur, A.; Singh, T.G.; Bedi, O. Pathobiological and molecular connections involved in the high fructose and high fat diet induced diabetes associated non-alcoholic fatty liver disease. Inflammation Res. 2020, 69, 851-867, https://doi.org/10.1007/s00011-020-01373-7.

15. Vivek Kumar, S.; Thakur Gurjeet, S. Chronic Stress and Diabetes Mellitus: Interwoven Pathologies. Curr. Diabetes Rev. 2020, 16, 546-556, https://doi.org/10.2174/1573399815666191111152248.

16. Chowdhury, T.; Mandal, A.; Roy, S.C.; De Sarker, D. Diversity of the genus Ocimum (Lamiaceae) through morpho-molecular (RAPD) and chemical (GC-MS) analysis. Journal of Genetic Engineering and Biotechnology 2017, 15, 275-286, https://doi.org/10.1016/j.jgeb.2016.12.004.

17. Swinburn, B.A.; Sacks, G.; Hall, K.D.; McPherson, K.; Finegood, D.T.; Moodie, M.L.; Gortmaker, S.L. The global obesity pandemic: shaped by global drivers and local environments. The Lancet 2011, 378, 804-814, https://doi.org/10.1016/s0140-6736(11)60813-1.

18. Wang, Y.C.; McPherson, K.; Marsh, T.; Gortmaker, S.L.; Brown, M. Health and economic burden of the projected obesity trends in the USA and the UK. The Lancet 2011, 378, 815-825, https://doi.org/10.1016/s01406736(11)60814-3.

19. Rtveladze, K.; Marsh, T.; Barquera, S.; Romero, L.M.S.; Levy, D.; Melendez, G.; Webber, L.; Kilpi, F.; McPherson, K.; Brown, M. Obesity prevalence in Mexico: impact on health and economic burden. Public Health Nutr. 2014, 17, 233-239, https://doi.org/10.1017/s1368980013000086.

20. Misra, A.; Chowbey, P.; Makkar, B.M.; Vikram, N.K.; Wasir, J.S.; Chadha, D.; Joshi, S.R.; Sadikot, S.; Gupta, R.; Gulati, S.; Munjal, Y.P. Consensus statement for diagnosis of obesity, abdominal obesity and the metabolic syndrome for Asian Indians and recommendations for physical activity, medical and surgical management. $J$. Assoc. Physicians India 2009, 57, 163-170.

21. Galassi, A.; Reynolds, K.; He, J. Metabolic syndrome and risk of cardiovascular disease: a meta-analysis. The American journal of medicine 2006, 119, 812-819, https://doi.org/10.1016/j.amjmed.2006.02.031.

22. Liu, T.-T.; Liu, X.-T.; Chen, Q.-X.; Shi, Y. Lipase Inhibitors for Obesity: A Review. Biomed. Pharmacother. 2020, 128, 110314, https://doi.org/10.1016/j.biopha.2020.110314.

23. Birari, R.B.; Bhutani, K.K. Pancreatic lipase inhibitors from natural sources: unexplored potential. Drug Discov. Today 2007, 12, 879-889, http://doi.org/10.1016/j.drudis.2007.07.024.

24. Mitchell, A.A.; Cassia, S.M.; Amar, G.C.; Theodore, W.K.; Harrihar, A.P. Type 2 Diabetes and Oral Antihyperglycemic Drugs. Curr. Med. Chem. 2008, 15, 61-74, https://doi.org/10.2174/092986708783330656.

25. Grewal, A.K.; Arora, S.; Singh, T.G. Role of Protein Kinase C in Diabetic Complications. Journal of Pharmaceutical Technology, Research and Management 2019, 7, 87-95, https://doi.org/10.15415/jptrm.2019.72011.

26. Singh, T.G.; Singh, H.P.; Kaur, S.; Dhiman, S. Protective effects of sesamol against cisplatin-induced nephrotoxicity in rats: A mechanistic approach. Obesity Medicine 2020, 19, 100269, https://doi.org/10.1016/j.obmed.2020.100269.

27. Mo, R.; Jiang, T.; Di, J.; Tai, W.; Gu, Z. Emerging micro- and nanotechnology based synthetic approaches for insulin delivery. Chem. Soc. Rev. 2014, 43, 3595-3629, https://doi.org/10.1039/C3CS60436E.

28. Singh, R.; Rao, H.K.; Singh, T.G. Advanced glycated end products (ages) in diabetes and its complications: an insight. Plant Archives 2020, 20, 3838-3841.

29. Zoller, H.; Tilg, H. Non-alcoholic fatty liver disease and hepatocellular carcinoma. Metabolism 2016, 65, 11511160, https://doi.org/10.1016/j.metabol.2016.01.010.

30. Daubioul, C.A.; Taper, H.S.; De Wispelaere, L.D.; Delzenne, N.M. Dietary Oligofructose Lessens Hepatic Steatosis, but Does Not Prevent Hypertriglyceridemia in Obese Zucker Rats. The Journal of Nutrition 2000, 130, 1314-1319, https://doi.org/10.1093/jn/130.5.1314. 
31. Macnaughtan, J.; Jalan, R. Clinical and Pathophysiological Consequences of Alterations in the Microbiome in Cirrhosis. Official journal of the American College of Gastroenterology | ACG 2015, 110, https://doi.org/10.1038/ajg.2015.313.

32. Ibragic, S.; Sofić, E. Chemical composition of various Ephedra species. Bosnian journal of basic medical sciences 2015, 15, 21, https://dx.doi.org/10.17305\%2Fbjbms.2015.539.

33. Shitiz, K.; Gupta, S.P. Chapter 8 - Rauwolfia serpentina. In Himalayan Medicinal Plants, Malhotra, N., Singh, M., Eds. Academic Press: 2021, https://doi.org/10.1016/B978-0-12-823151-7.00009-X.

34. Joshi, B.; Sah, G.P.; Basnet, B.B.; Bhatt, M.R.; Sharma, D.; Subedi, K.; Janardhan, P.; Malla, R. Phytochemical extraction and antimicrobial properties of different medicinal plants: Ocimum sanctum (Tulsi), Eugenia caryophyllata (Clove), Achyranthes bidentata (Datiwan) and Azadirachta indica (Neem). Journal of microbiology and Antimicrobials 2011, 3, 1-7.

35. Oguntibeju, O.O. Medicinal plants with anti-inflammatory activities from selected countries and regions of Africa. Journal of inflammation research 2018, 11, 307, https://dx.doi.org/10.2147\%2FJIR.S167789.

36. Thumann, T.A.; Pferschy-Wenzig, E.-M.; Moissl-Eichinger, C.; Bauer, R. The role of gut microbiota for the activity of medicinal plants traditionally used in the European Union for gastrointestinal disorders. $J$. Ethnopharmacol. 2019, 245, 112153, https://doi.org/10.1016/j.jep.2019.112153.

37. Bhateja, S.; Arora, G. THERAPEUTIC BENEFITS OF HOLY BASIL (TULSI) IN GENERAL AND ORAL MEDICINE: A REVIEW. International Journal of Research in Ayurveda \& Pharmacy 2012, 3, https://doi.org/\%2F10.7897\%2F2277-4343.03611.

38. Baliga, M.S.; Jimmy, R.; Thilakchand, K.R.; Sunitha, V.; Bhat, N.R.; Saldanha, E.; Rao, S.; Rao, P.; Arora, R.; Palatty, P.L. Ocimum Sanctum L (Holy Basil or Tulsi) and Its Phytochemicals in the Prevention and Treatment of Cancer. Nutr. Cancer 2013, 65, 26-35, https://doi.org/10.1080/01635581.2013.785010.

39. Hanumanthaiah, P.; Panari, H.; Chebte, A.; Haile, A.; Belachew, G. Tulsi (Ocimum sanctum)-a myriad medicinal plant, secrets behind the innumerable benefits. Arabian Journal of Medicinal and Aromatic Plants 2020, 6, 105127, https://doi.org/10.48347/IMIST.PRSM/ajmap-v6i1.20401.

40. Prabhu, K.S.; Lobo, R.; Shirwaikar, A.A.; Shirwaikar, A. Ocimum gratissimum: A review of its chemical, pharmacological and ethnomedicinal properties. The Open Complementary Medicine Journal 2009, 1, http://dx.doi.org/10.2174/1876391X00901010001.

41. Zengin, G.; Ferrante, C.; Gnapi, D.E.; Sinan, K.I.; Orlando, G.; Recinella, L.; Diuzheva, A.; Jekő, J.; Cziáky, Z.; Chiavaroli, A.; Leone, S.; Brunetti, L.; Picot-Allain, C.; Mahomoodally, M.F.; Angelini, P.; Covino, S.; Venanzoni, R.; Tirillini, B.; Menghini, L. Comprehensive approaches on the chemical constituents and pharmacological properties of flowers and leaves of American basil (Ocimum americanum L). Food Res. Int. 2019, 125, 108610, https://doi.org/10.1016/j.foodres.2019.108610.

42. Pattanayak, P.; Behera, P.; Das, D.; Panda, S.K. Ocimum sanctum Linn. A reservoir plant for therapeutic applications: An overview. Pharmacogn Rev. 2010, 4, 95, https://dx.doi.org/10.4103\%2F0973-7847.65323.

43. Ademiluyi, A.O.; Oyeleye, S.I.; Oboh, G. Biological activities, antioxidant properties and phytoconstituents of essential oil from sweet basil (Ocimum basilicum L.) leaves. Comp. Clin. Path. 2016, 25, 169-176, http://dx.doi.org/10.1007\%2Fs00580-015-2163-3.

44. Jamshidi, N.; Cohen, M.M. The Clinical Efficacy and Safety of Tulsi in Humans: A Systematic Review of the Literature. Evid. Based Complement. Alternat. Med. 2017, 2017, 9217567, https://doi.org/10.1155/2017/9217567.

45.Goswami, B.; Akter, S.; Nandi, N.C.; Banu, T.A.; Akter, S.; Afrin, S.; Habib, A.; Khan, S. Antioxidant and Antibacterial Activities of Four Local Medicinal Plants. Plant Tissue Culture and Biotechnology 2020, 30, 179187.

46. Gamal-Eldeen, A.M.; Amer, H.; Helmy, W.A.; Ragab, H.M.; Talaat, R.M. Antiproliferative and cancerchemopreventive properties of sulfated glycosylated extract derived from Leucaena leucocephala. Indian J. Pharm. Sci. 2007, 69, 805, https://doi.org/10.4103/0250-474X.39438.

47. Falowo, A.B.; Mukumbo, F.E.; Idamokoro, E.M.; Afolayan, A.J.; Muchenje, V. Phytochemical constituents and antioxidant activity of sweet basil (Ocimum basilicum L.) Essential Oil on Ground Beef from Boran and Nguni Cattle. International Journal of Food Science 2019, 2019, 2628747, https://doi.org/10.1155/2019/2628747.

48. Mishra, L.K.; Sarkar, D.; Mentreddy, R.; Shetty, K. Evaluation of phenolic bioactive-linked anti-hyperglycemic and Helicobacter pylori inhibitory activities of Asian Basil (Ocimum spp.) varieties. Journal of Herbal Medicine 2020, 20, 100310,https://doi.org/10.1016/j.hermed.2019.100310.

49. Siva, M.; Shanmugam, K.R.; Shanmugam, B.; Venkata, S.G.; Ravi, S.; Sathyavelu, R.K.; Mallikarjuna, K. Ocimum sanctum: a review on the pharmacological properties. Int. J. Basic Clin. Pharmacol 2016, 5, 558-565, http://dx.doi.org/10.18203/2319-2003.ijbcp20161491. 
50. Bayala, B.; Bassole, I.H.N.; Gnoula, C.; Nebie, R.; Yonli, A.; Morel, L.; Figueredo, G.; Nikiema, J.-B.; Lobaccaro, J.-M.A.; Simpore, J. Chemical Composition, Antioxidant, Anti-Inflammatory and Anti-Proliferative Activities of Essential Oils of Plants from Burkina Faso. PLoS One 2014, 9, e92122, https://doi.org/10.1371/journal.pone.0092122.

51. Okoduwa, S.I.R.; Umar, I.A.; James, D.B.; Inuwa, H.M. Appropriate Insulin Level in Selecting Fortified Diet-Fed, Streptozotocin-Treated Rat Model of Type 2 Diabetes for Anti-Diabetic Studies. PLoS One 2017, 12, e0170971, https://doi.org/10.1371/journal.pone.0170971.

52. Sudhakar, K.; Mishra, V.; Hemani, V.; Verma, A.; Jain, A.; Jain, S.; Charyulu, R.N. Reverse pharmacology of phytoconstituents of food and plant in the management of diabetes: Current status and perspectives. Trends Food Sci. Technol. 2021, 110, 594-610, https://doi.org/10.1016/j.tifs.2020.10.024.

53. Grover, J.K.; Vats, V.; Yadav, S.S. Pterocarpus marsupium extract (Vijayasar) prevented the alteration in metabolic patterns induced in the normal rat by feeding an adequate diet containing fructose as sole carbohydrate. Diabetes, Obesity and Metabolism 2005, 7, 414-420, https://doi.org/10.1111/j.1463-1326.2005.00414.x.

54. Vats, V.; Yadav, S.P.; Grover, J.K. Ethanolic extract of Ocimum sanctum leaves partially attenuates streptozotocininduced alterations in glycogen content and carbohydrate metabolism in rats. J. Ethnopharmacol. 2004, 90, 155160, https://doi.org/10.1016/j.jep.2003.09.034.

55. Okoduwa, S.I.R.; Umar, I.A.; James, D.B.; Inuwa, H.M. Anti-Diabetic Potential of Ocimum gratissimum Leaf Fractions in Fortified Diet-Fed Streptozotocin Treated Rat Model of Type-2 Diabetes. Medicines 2017, 4, https://doi.org/10.3390/medicines4040073.

56. Egesie, U.G.; Adelaiye, A.B.; Ibu, J.O.; Egesie, O.J. Safety and hypoglycaemic properties of aqueous leaf extract of Ocimum gratissimum in streptozotocin induced diabetic rats. Niger. J. Physiol. Sci. 2006, 21, https://doi.org/10.4314/njps.v21i1-2.53971.

57. Ezuruike, U.F.; Prieto, J.M. The use of plants in the traditional management of diabetes in Nigeria: Pharmacological and toxicological considerations. J. Ethnopharmacol. $\quad \mathbf{2 0 1 4}, \quad$ 155, $\quad 857-924$, https://doi.org/10.1016/j.jep.2014.05.055.

58. Mohammed, A.; Ibrahim, M.A.; Islam, M.S. African medicinal plants with anti-diabetic potentials: A review. Planta Med. 2014, 80, 354-377, https://doi.org/10.1055/s-0033-1360335.

59. Shittu, S.-T.T.; Oyeyemi, W.A.; Lasisi, T.J.; Shittu, S.A.-S.; Lawal, T.T.; Olujobi, S.T. Aqueous leaf extract of Ocimum gratissimum improves hematological parameters in alloxan-induced diabetic rats via its antioxidant properties. International Journal of Applied and Basic Medical Research 2016, 6, 96, https://dx.doi.org/10.4103\%2F2229-516X.179016.

60. Ekoh, S.N.; Akubugwo, E.I.; Ude, V.C.; Edwin, N. Anti-hyperglycemic and anti-hyperlipidemic effect of spices (Thymus vulgaris, Murraya koenigii, Ocimum gratissimum and Piper guineense) in alloxan-induced diabetic rats. Int J Biosci 2014, 4, 179-187, http://dx.doi.org/10.12692/ijb/4.2.179-187.

61. Shimada, H.; Kuma, C.; Iseri, T.; Matsumura, S.-i.; Kawase, A.; Matsuura, M.; Iwaki, M. Inhibitory Effect of Ocimum gratissimum Leaf Extract on Postprandial Increase of Blood Glucose. Nat. Prod. Commun. 2019, 14, 1934578X19883728, https://doi.org/10.1177\%2F1934578X19883728.

62. Ezeani, C.; Ezenyi, I.; Okoye, T.; Okoli, C. Ocimum basilicum extract exhibits anti-diabetic effects via inhibition of hepatic glucose mobilization and carbohydrate metabolizing enzymes. Journal of intercultural ethnopharmacology2017, 6, 22, https://dx.doi.org/10.5455\%2Fjice.20161229054825.

63. El-Beshbishy, H.A.; Bahashwan, S.A. Hypoglycemic effect of basil (Ocimum basilicum) aqueous extract is mediated through inhibition of $\alpha$-glucosidase and $\alpha$-amylase activities: an in vitro study. Toxicology and Industrial Health 2012, 28(1), 42-50, https://doi.org/10.1177\%2F0748233711403193.

64. Widjaja, S.s.; Dr, R.; Savira, M. Glucose Lowering Effect of Basil Leaves in Diabetic Rats. Open access Macedonian journal of medical sciences 2019, 7, 1415-1417, https://dx.doi.org/10.3889/oamjms.2019.293.

65. Wang, Z.; Li, H.; Wang, J.; Chen, Z.; Chen, G.; Wen, D.; Chan, A.; Gu, Z. Transdermal colorimetric patch for hyperglycemia sensing in diabetic mice. Biomaterials 2020, 237, 119782 , https://doi.org/10.1016/j.biomaterials.2020.119782.

66. Singh, P.; Jayaramaiah, R.H.; Agawane, S.B.; Vannuruswamy, G.; Korwar, A.M.; Anand, A.; Dhaygude, V.S.; Shaikh, M.L.; Joshi, R.S.; Boppana, R.; Kulkarni, M.J.; Thulasiram, H.V.; Giri, A.P. Potential Dual Role of Eugenol in Inhibiting Advanced Glycation End Products in Diabetes: Proteomic and Mechanistic Insights. Sci. Rep. 2016, 6, 18798, https://dx.doi.org/10.1038\%2Fsrep18798.

67. Modak, M.; Dixit, P.; Londhe, J.; Ghaskadbi, S.; Devasagayam, T.P.A. Indian Herbs and Herbal Drugs Used for the Treatment of Diabetes. J. Clin. Biochem. Nutr. 2007, 40, 163-173, https://doi.org/10.3164/jcbn.40.163. 
68. Irondi, E.A.; Agboola, S.O.; Oboh, G.; Boligon, A.A. Inhibitory effect of leaves extracts of Ocimum basilicum and Ocimum gratissimum on two key enzymes involved in obesity and hypertension in vitro. Journal of intercultural ethnopharmacology2016, 5, 396, https://dx.doi.org/10.5455\%2Fjice.20160814112756.

69. Rahmouni, K.; Correia Marcelo, L.G.; Haynes William, G.; Mark Allyn, L. Obesity-Associated Hypertension. Hypertension 2005, 45, 9-14, https://doi.org/10.1161/01.HYP.0000151325.83008.b4.

70. Guerrero, L.; Castillo, J.; Quiñones, M.; Garcia-Vallvé, S.; Arola, L.; Pujadas, G.; Muguerza, B. Inhibition of Angiotensin-Converting Enzyme Activity by Flavonoids: Structure-Activity Relationship Studies. PLoS One 2012, 7, e49493, https://doi.org/10.1371/journal.pone.0049493.

71. Pérez-Ramírez, I.F.; González-Dávalos, M.L.; Mora, O.; Gallegos-Corona, M.A.; Reynoso-Camacho, R. Effect of Ocimum sanctum and Crataegus pubescens aqueous extracts on obesity, inflammation, and glucose metabolism. $J$. Funct. Foods 2017, 35, 24-31, https://doi.org/10.1016/j.jff.2017.05.028.

72. Zheng, E.; Sandhu, N.; Navarro, V. Drug-induced Liver Injury Secondary to Herbal and Dietary Supplements. Clin. Liver Dis. 2020, 24, 141-155, https://doi.org/10.1016/j.cld.2019.09.009.

73. Santos, G.; Gasca, J.; Parana, R.; Nunes, V.; Schinnoni, M.; Medina-Caliz, I.; Cabello, M.R.; Lucena, M.I.; Andrade, R.J. Profile of herbal and dietary supplements induced liver injury in Latin America: A systematic review of published reports. Phytother. Res. 2021, 35, 6-19, https://doi.org/10.1002/ptr.6746.

74. Prakash, P.; Gupta, N. Therapeutic uses of Ocimum sanctum Linn (Tulsi) with a note on eugenol and its pharmacological actions: a short review. Indian J. Physiol. Pharmacol. 2005, 49, 125-131.

75. Lahon, K.; Das, S. Hepatoprotective activity of Ocimum sanctum alcoholic leaf extract against paracetamolinduced liver damage in Albino rats. Pharmacognosy research2011, 3, 13-18, https://dx.doi.org/10.4103\%2F09748490.79110 .

76. Renovaldi, D.; Adam, A.K. Potential of Sweet Basil (Ocimum basilicum) as a Hepatoprotector Agent for Liver Injury Related to Drugs. Muhammadiyah Medical Journal2020, 1, 21-6, https://doi.org/10.24853/mmj.1.2.63-68.

77. Sakr, S.A.; Nooh, H.Z. Effect of Ocimum basilicum extract on cadmium-induced testicular histomorphometric and immunohistochemical alterations in albino rats. Anatomy \& cell biology 2013, 46, 122-130, https://doi.org/10.5115/acb.2013.46.2.122.

78. Marzouk, A.M. Hepatoprotective Triterpenes from Hairy Root Cultures of Ocimum basilicum L. Zeitschrift für Naturforschung C 2009, 64, 201-209, https://doi.org/10.1515/znc-2009-3-409.

79. Aluko, B.T.; Oloyede, O.I.; Afolayan, A.J. Hepatoprotective activity of Ocimum americanum L leaves against paracetamol- induced liver damage in rats. Am. J. Life Sci. 2013, 1, 37-42, https://doi.org/10.11648/j.ajls.20130102.13.

80. Genfi, A.K.A.; Larbie, C.; Emikpe, B.O.; Oyagbemi, A.A.; Firempong, C.K.; Adjei, C.O. Modulation of Oxidative Stress and Inflammatory Cytokines as Therapeutic Mechanisms of Ocimum americanum L Extract in Carbon Tetrachloride and Acetaminophen-Induced Toxicity in Rats. Journal of Evidence-Based Integrative Medicine 2020, 25, 2515690X20938002, https://doi.org/10.1177\%2F2515690X20938002.

81. Touiss, I.; Ouahhoud, S.; Harnafi, M.; Khatib, S.; Bekkouch, O.; Amrani, S.; Harnafi, H. Toxicological Evaluation and Hepatoprotective Efficacy of Rosmarinic Acid-Rich Extract from Ocimum basilicum L. Evid. Based Complement. Alternat. Med. 2021, 2021, 6676998, https://doi.org/10.1155/2021/6676998.

82. Boaventura, T.P.; Souza, C.F.; Ferreira, A.L.; Favero, G.C.; Baldissera, M.D.; Heinzmann, B.M.; Baldisserotto, B.; Luz, R.K. The use of Ocimum gratissimum L. essential oil during the transport of Lophiosilurus alexandri: Water quality, hematology, blood biochemistry and oxidative stress. Aquaculture 2021, 531, 735964, https://doi.org/10.1016/j.aquaculture.2020.735964.

83. Gabal, A,M. Basil (Ocimum basilicum L.) and/or Celery (Apium graveolens L.) Leaves Aqueous Extracts Role in Opposition to Drinking Contaminated Water Induced Male Rats Urinary Stones and Renal Deteriorations. Annual Research \& Review in Biology 2020, 52-65, https://doi.org/10.9734/arrb/2020/v35i1130299.

84. Lee, D. H.; Lee, J.; Jeon, J.; Kim, K.J.; Yun, J.H.; Jeong, H.S.; Lee, E.H.; Koh, Y.J.; Cho, C.H. Oleanolic Acids Inhibit Vascular Endothelial Growth Factor Receptor 2 Signaling in Endothelial Cells: Implication for AntiAngiogenic Therapy. Molecules and cells 2018, 41, 771-780, https://doi.org/10.14348/molcells.2018.0207.

85. Okoye, F.B.; Obonga, W.O.; Onyegbule, F.A.; Ndu, O.O.; Ihekwereme, C.P. Chemical composition and antiinflammatory activity of essential oils from the leaves of Ocimum basilicum L. and Ocimum gratissimum L.(Lamiaceae). International Journal of Pharmaceutical Sciences and Research 2014, 5, 2174, https://doi.org/10.13040/IJPSR.0975-8232.5(6).2174-80.

86. Noor, Z.I.; Ahmed, D.; Rehman, H.M.; Qamar, M.T.; Froeyen, M.; Ahmad, S.; Mirza, M.U. In Vitro Antidiabetic, Anti-Obesity and Antioxidant Analysis of Ocimum basilicum Aerial Biomass and in Silico Molecular Docking Simulations with Alpha-Amylase and Lipase Enzymes. Biology 2019, 8, https://doi.org/10.3390/biology8040092. 
87. Nangle, M.R.; Gibson, T.M..; Cotter, M.A.; Cameron, N.E. Effects of Eugenol on nerve and vascular dysfunction in streptozotocin-diabetic rats. Planta medica 2006, 72, 494-500, https://doi.org/10.1055/s-2005-916262.

88. Garud, M.S.; Kulkarni, Y.A. Eugenol ameliorates renal damage in streptozotocin-induced diabetic rats. Flavour Fragrance J. 2017, 32, 54-62, https://doi.org/10.1002/ffj.3357.

89. Xu, H.-1.; Wang, X.-t.; Cheng, Y.; Zhao, J.-g.; Zhou, Y.-j.; Yang, J.-j.; Qi, M.-y. Ursolic acid improves diabetic nephropathy via suppression of oxidative stress and inflammation in streptozotocin-induced rats. Biomed. Pharmacother. 2018, 105, 915-921, https://doi.org/10.1016/j.biopha.2018.06.055.

90. Matboli, M.; Eissa, S.; Ibrahim, D.; Hegazy, M.G.A.; Imam, S.S.; Habib, E.K. Caffeic Acid Attenuates Diabetic Kidney Disease via Modulation of Autophagy in a High-Fat Diet/Streptozotocin- Induced Diabetic Rat. Sci. Rep. 2017, 7, 2263, https://doi.org/10.1038/s41598-017-02320-z.

91. Satapathy, S.; Das, N.; Bandyopadhyay, D.; Mahapatra, S.C.; Sahu, D.S.; Meda, M. Effect of Tulsi (Ocimum sanctum Linn.) Supplementation on Metabolic Parameters and Liver Enzymes in Young Overweight and Obese Subjects. Indian J. Clin. Biochem. 2017, 32, 357-363, https://doi.org/10.1007/s12291-016-0615-4.

92. Casanova, L.M.; Gu, W.; Costa, S.S.; Jeppesen, P.B. Phenolic Substances from Ocimum Species Enhance GlucoseStimulated Insulin Secretion and Modulate the Expression of Key Insulin Regulatory Genes in Mice Pancreatic Islets. J. Nat. Prod. 2017, 80, 3267-3275, https://doi.org/10.1021/acs.jnatprod.7b00699.

93. Takeuchi, H.; Takahashi-Muto, C.; Nagase, M.; Kassai, M.; Tanaka-Yachi, R.; Kiyose, C. Anti-inflammatory Effects of Extracts of Sweet Basil (Ocimum basilicum L.) on a Co-culture of 3T3-L1 Adipocytes and RAW264. 7 Macrophages. Journal of Oleo Science 2020, 69, 487-493, https://doi.org/10.5650/jos.ess19321.

94. Yousefi-Manesh, H.; Dejban, P.; Mumtaz, F.; Abdollahi, A.; Chamanara, M.; Dehpour, A.; Hasanvand, A.; Rashidian, A. Risperidone attenuates acetic acid-induced colitis in rats through inhibition of TLR4/NF-kB signaling pathway. Immunopharmacol. Immunotoxicol. $\quad \mathbf{2 0 2 0} \quad 42, \quad 464-472$, https://doi.org/10.1080/08923973.2020.1808987.

95. Suleiman, J.B.; Abu Bakar, A.B.; Mohamed, M. Review on effects of obesity on male reproductive system and the role of natural products. J. Appl. Pharm. Sci.2019, 9, 131-41, https://doi.org/10.7324/JAPS.2019.90118.

96. Gurjar, V.K.; Pal, D. Natural Compounds Extracted from Medicinal Plants and Their Immunomodulatory Activities. In Bioactive Natural Products for Pharmaceutical Applications, Pal, D., Nayak, A.K., Eds. Springer International Publishing: Cham, 2021; https://doi.org/10.1007/978-3-030-54027-2_6.

97. Jamshidi, N.; Da Costa, C.; Cohen, M. Holybasil (tulsi) lowers fasting glucose and improves lipid profile in adults with metabolic disease: A meta-analysis of randomized clinical trials. J. Funct. Foods 2018, 45, 47-57, https://doi.org/10.1016/j.jff.2018.03.030.

98. Venkatesan, P.; Sengupta, R. Effect of supplementation of Tulsi leaves or curry leaves or combination of both type 2 diabetes. International Journal of Pure \& Applied Bioscience (IJPAB) 2015, 3, 331-337.

99. Ahmad, M.; Faraazi, A.A.; Aamir, M.N. The effect of Ocimum sanctum and ledum palustre on serum uric acid level in patients suffering from gouty arthritis and hyperuricaemia. Bulletin of the Chemical Society of Ethiopia 2013, 27, 469-473, https://doi.org/10.4314/bcse.v27i3.16.

100.Devra, D.K.; Mathur, K.C.; Agrawal, R.P.; Bhadu, I.; Goyal, S.; Agarwal, V. Effect of Tulsi (Ocimum sanctum Linn.) on clinical and biochemical parameters of metabolic syndrome. Journal of Natural Remedies 2012, 12, 6367, https://doi.org/10.18311/jnr/2012/38.

101.Pulipati, V.P.; Ravi, V.; Pulipati, P. Cardiovascular outcomes with glucagon-like peptide-1 receptor agonists in patients with type 2 diabetes mellitus: A systematic review and meta-analysis. European Journal of Preventive Cardiology 2020, 27, 1922-1930, https://doi.org/10.1177\%2F2047487320903638.

102.Pandiri, I.; Moni, A. Ocimum herb species: a potential treatment strategy for diabetic kidney disease. Journal of Advanced Biotechnology and Experimental Therapeutics 2018, 1, 88-91, https://doi.org/10.5455/jabet.2018.d16.

103. Bhargava, A.; Gangwar, L.; Grewal, H.S. To Study the Effect of Holy Basil Leaves on Low Blood Pressure (Hypotension ) Women Aged 18-30 years. In International Conference on Food and Agricultural Sciences 2013, $55,83-86$. 